NBER WORKING PAPER SERIES

THE FRAGILITY OF ESTIMATED EFFECTS OF UNILATERAL DIVORCE LAWS ON DIVORCE RATES

\author{
Jin Young Lee \\ Gary Solon \\ Working Paper 16773 \\ http://www.nber.org/papers/w16773
NATIONAL BUREAU OF ECONOMIC RESEARCH
1050 Massachusetts Avenue
Cambridge, MA 02138
February 2011

We are very grateful to Justin Wolfers for posting his data and code and for gracious and insightful comments on an earlier draft. We also thank Stacy Dickert-Conlin, Todd Elder, Steven Haider, Do Won Kwak, and Stephen Woodbury for their helpful advice. The views expressed herein are those of the authors and do not necessarily reflect the views of the National Bureau of Economic Research.

NBER working papers are circulated for discussion and comment purposes. They have not been peerreviewed or been subject to the review by the NBER Board of Directors that accompanies official NBER publications.

(C) 2011 by Jin Young Lee and Gary Solon. All rights reserved. Short sections of text, not to exceed two paragraphs, may be quoted without explicit permission provided that full credit, including (C notice, is given to the source. 
The Fragility of Estimated Effects of Unilateral Divorce Laws on Divorce Rates

Jin Young Lee and Gary Solon

NBER Working Paper No. 16773

February 2011

JEL No. C23,J12,K36

\begin{abstract}
$\underline{\text { ABSTRACT }}$
Following an influential article by Friedberg (1998), Wolfers (2006) explored the sensitivity of Friedberg's results to allowing for dynamics in the response of divorce rates to the adoption of unilateral divorce laws. We in turn explore the sensitivity of Wolfers's results to variations in estimation method and functional form, and we find that the results are extremely fragile. We conclude first that the impact of unilateral divorce laws remains unclear. Second, extending Wolfers's methodological insight about sensitivity of differences-in-differences estimation to allowance for dynamic response, we suggest that identification in differences-in-differences research becomes weaker in the presence of dynamics, especially in the presence of unit-specific time trends.
\end{abstract}

Jin Young Lee

Department of Economics

Michigan State University

East Lansing, MI 48824-1038

leejin9@msu.edu

Gary Solon

Department of Economics

Michigan State University

East Lansing, MI 48824-1038

and NBER

solon@msu.edu 


\section{The Fragility of Estimated Effects of Unilateral Divorce Laws on Divorce Rates}

An influential American Economic Review article by Leora Friedberg (1998) estimated the impact on divorce rates from the adoption of unilateral divorce laws by most states during the 1970s. Using state/year data for 1968-1988, Friedberg estimated fixed-effects regressions of the per-capita divorce rate on a dummy variable for unilateral divorce with controls for state effects and year effects. In the simplest specification, she estimated almost exactly a zero effect of unilateral divorce, but in her preferred specifications that also controlled for linear or quadratic state-specific time trends, she estimated that adoption of unilateral divorce increased the divorce rate by more than 0.4 divorces per 1,000 population. This estimated impact seemed substantial relative to the sample mean divorce rate of 4.6, and Friedberg concluded (p. 608), "The move towards unilateral divorce accounted for 17 percent of the increase in divorce rates between 1968 and 1988."

In a subsequent American Economic Review article, Justin Wolfers (2006) questioned Friedberg's assumption that unilateral divorce shifted the divorce rate by a permanent constant. Instead, he posed the possibility that the impact might follow a distributed-lag pattern. Expanding the sample period to 1956-1988, he estimated regressions similar to Friedberg's except that he replaced her single dummy variable for unilateral divorce with a series of dummies indicating that unilateral divorce had been in place for up to 2 years, 3-4 years, 5-6 years, ..., 13-14 years, or at least 15 years. Based on the results, he concluded (p. 1802) "that the divorce rate rose sharply following the adoption of unilateral divorce laws, but that this rise was reversed within about a decade.” In the present comment, we check the robustness of Wolfers's estimates to some reasonable variations in estimation method and functional form. ${ }^{1}$

\section{Robustness Checks}

\section{A. Weighted and Ordinary Least Squares Estimates of Linear-in-Levels Specifications}

Like Friedberg, Wolfers estimated his regressions by weighted least squares (WLS), weighting each state/year observation by the state's population. The results are shown in the first columns of our tables 1,2 , and 3 , respectively for models with no state-specific trends, linear

\footnotetext{
${ }^{1}$ It is understandable that Wolfers hewed closely to Friedberg's estimation method and functional form in an effort to explore the role of dynamics while holding these other factors constant.
} 
trends, and quadratic trends. Thanks to Wolfers's generous posting of his data and code on his website, it was easy to obtain exact replications of his results. In all three specifications, unilateral divorce is estimated to increase the divorce rate initially by about 0.3 divorces per 1,000 population. The basis for Wolfers's conclusion about dynamics is that the impact appears to remain substantial throughout the first eight years since adoption, but beyond eight years there is little evidence of a substantial positive impact.

Like Friedberg, Wolfers estimated his standard errors (shown in parentheses in the first columns of our tables 1-3) on the assumption that the error term in each weighted regression is homoskedastic and serially uncorrelated. Setting aside the homoskedasticity assumption for the moment, our analysis of the residuals from Wolfers's regressions shows overwhelming evidence of strong serial correlation. First-order autoregressions of the WLS residuals show estimated autocorrelations of $0.93,0.90$, and 0.88 respectively for the three specifications. Furthermore, the estimated autocorrelations remain substantial at higher orders. For example, the respective estimates of the fifth-order autocorrelations are $0.69,0.60$, and $0.58 .^{2}$ Obviously, neglect of such strong serial correlation could lead to serious bias in the estimation of standard errors. We therefore have used Stata's cluster option to implement Arellano's (1987) method of correcting standard error estimates for both serial correlation and heteroskedasticity. The resulting standard error estimates, shown in brackets in the first columns of our tables 1-3, are dramatically larger than those reported by Wolfers. Once it is recognized that the coefficient estimates may be much less precise than they previously appeared, the statistical significance of the coefficient estimates for lags up to eight years becomes less compelling. ${ }^{3}$

An even more striking pattern emerges when we reconsider whether weighting by population is an appropriate correction for heteroskedasticity. The common practice of weighting by population leads to efficient coefficient estimation under the very strong assumption that the error terms for individuals within the state are homoskedastic and independent of each other. As explained in detail by Dickens (1990), however, in the likely case

\footnotetext{
${ }^{2}$ As shown in Nickell (1981) and Solon (1984), these estimates are biased downward by the incidental-parameters problem in fixed-effects estimation. With a time-series length of 33 years, however, the bias is small.

${ }^{3}$ This same point is made by Vogelsang (2008) with respect to the model with no state-specific trends. We say "may be less precise" rather than "are less precise" because Vogelsang goes on to find that, when he also applies his method for correcting for spatial correlation (correlation among error terms across states), the standard error estimates come back down. In the end, Wolfers's assumption of homoskedasticity and no serial correlation clearly is incorrect, but it is not so clear what the precision of the coefficient estimates really is.
} 
that the individual error terms are positively correlated because they share a common state-level error component, the original (unweighted) state-average error terms may be nearly homoskedastic, and weighting by population size may induce a substantial heteroskedasticity problem. In this case, ordinary least squares (OLS) may be considerably more efficient than WLS. At minimum, then, it is good practice to report coefficient estimates from both methods, along with heteroskedasticity-robust standard error estimates. Also, as emphasized by DuMouchel and Duncan (1983), since both estimators are consistent if the model otherwise is correctly specified, discrepancies between WLS and OLS estimates can be a basis for testing model specification.

In the second columns of tables 1-3, we report the results from estimating by OLS instead of WLS. Where the WLS coefficient estimates for lags up to eight years had appeared substantially positive, this is much less true for the OLS coefficient estimates in all three specifications. This same finding has been reported by Dröes and van Lamoen (2010). Furthermore, in accordance with Dickens's critique of population-weighting, although the robust standard error estimates (shown in brackets) appear larger for OLS than for WLS in table 1, this is less clear for the specifications in tables 2 and 3.

In any case, the substantial discrepancies between the WLS and OLS estimates are suggestive of model misspecification. We will take up the issue of functional form in the next sub-section. Here, we will close by noting another potential specification issue - the assumption that the vector of distributed-lag coefficients is homogeneous across states may be incorrect. If the impact of unilateral divorce is heterogeneous - i.e., if it interacts with other state characteristics - then WLS and OLS estimates that do not explicitly account for those interactions may identify different averages of the heterogeneous effects. By design, WLS places more weight on the more populous states. If unilateral divorce tends to have larger effects in those states, then the WLS estimates will tend to be larger than the OLS estimates. This possibility is suggested by the results in the third columns of tables 1-3, which redo WLS with California omitted from the sample. The coefficient estimates are much smaller than the fullsample WLS results in the first columns. The discrepancy between the estimates in columns 1 
and 2 may arise partly because California looms large in the full-sample WLS estimates, but is weighted the same as any other state in the OLS estimates. ${ }^{4}$

\section{B. Alternative Functional Forms}

All the regression models estimated by Wolfers, as well as Friedberg, are linear models for the level of the divorce rate. This is not the only possible functional specification, and arguably not the most natural. For example, given that the divorce rate is always positive, linear models for the logarithm of the divorce rate are an obvious alternative. Indeed, since the divorce rate is a fraction, linear models for the logit of the divorce rate (i.e., the log odds of divorcing) also seem appealing. In practice, though, there is almost no difference in the present case between the log and the logit. With the divorce rate $R$ expressed per capita, the logit of $R$ is $\log [R /(1-R)]=\log R-\log (1-R)$, which is almost identical to $\log R$ because $\log (1-R)$ is so close to zero. In the rest of tables $1-3$, we report results for only the log of $R$ because the logit results are virtually identical.

The last two columns in tables 1-3 report both WLS and OLS estimates of models in which the dependent variable is the divorce rate in log rather than level form. We think this sensitivity analysis is our most striking of all. Once the divorce rate is in log form, neither the WLS nor OLS estimates show any indication of a positive effect of unilateral divorce on divorce rates in any of the three specifications. Whereas Friedberg and Wolfers differed over whether the positive impact of unilateral divorce on divorce rates is permanent or temporary, the log results show no positive impact at all. The fragility of the previously published estimates does not prove those estimates are wrong. Rather, the extreme sensitivity of the results to functional form assumptions, as well as estimation methods, leaves unclear what the true impact of unilateral divorce has been. ${ }^{5}$

Three other points about functional form are worth noting. First, the discrepancy between the levels results and the log (and logit) results is a vivid counter-example to the

\footnotetext{
${ }^{4}$ As noted by Friedberg (1998, footnote 20), Nevada is a major outlier with respect to divorce rates. We have found, however, that, with state fixed effects accounted for, excluding/including Nevada is much less consequential for the gap between WLS and OLS estimates than is the treatment of California.

${ }^{5}$ It may be worth adding that none of the estimates in our article, Wolfers's, or Friedberg's indicates that the adoption of unilateral divorce accounts for most of the rise in divorce rates during the 1970s. As Stevenson and Wolfers $(2007$, p. 46) put the point, "Despite apparent conflict in this literature, it is worth emphasizing the point of substantial agreement: each of these authors finds that liberalized divorce laws had at most a small effect on divorce rates, and these reforms explain very little of the rise in divorce over the past half century."
} 
frequent claim that functional form assumptions are of little consequence in the estimation of models for binary, fractional, or otherwise limited dependent variables. ${ }^{6}$ Second, compared to the levels specifications, the log specifications show less discrepancy between the WLS and OLS results. Third, with regard to Dickens's analysis of weighting, the robust standard error estimates for the log specifications suggest that, for those specifications, OLS is considerably more efficient than WLS.

\section{Summary and Discussion}

Our main substantive finding is that estimates of the impact of unilateral divorce laws on divorce rates are highly sensitive to variations in model specification and estimation method. We do not take this to mean that the conclusions in Wolfers (2006) are necessarily wrong. We take it to mean that the true impact of unilateral divorce laws remains unclear.

In addition, the Wolfers article appropriately emphasized broader methodological lessons. Having found that Friedberg's (1998) results seemed sensitive to allowance for dynamic response, Wolfers concluded (p. 1802),

A major difficulty in difference-in-difference analyses involves separating out preexisting trends from the dynamic effects of a policy shock. Her approach appears to confound the two. This problem - that state-specific trends may pick up the effects of a policy and not just preexisting trends - is quite general. Slight modifications to standard procedures yield more directly interpretable results.

We fully agree that, when the impact of a policy change is not necessarily immediate and constant, researchers should follow Wolfers's example of exploring the dynamics of the response. But the results we have reported suggest an additional cautionary note. The differences-in-differences research design with unit-specific time trends is essentially a type of regression discontinuity design, with time as the "running variable." As in other regression discontinuity designs, identification is based on the appearance and size of a "jump" in the dependent variable at the discontinuity point - in this case, the time at which the new policy is adopted. When the shift in the dependent variable may vary with the length of time since the

\footnotetext{
${ }^{6}$ For example, a lengthy passage on this topic in Angrist and Pischke (2009) concludes (p. 107), "The upshot of this discussion is that while a nonlinear model may fit the CEF [conditional expectation function] for LDVs [limited dependent variables] more closely than a linear model, when it comes to marginal effects, this probably matters little. This optimistic conclusion is not a theorem, but, as in the empirical example here, it seems to be fairly robustly true."
} 
policy change, and especially when that complication is accompanied by other differences across states in time trends, the sharpness of the identification strategy suffers. In such cases, we are asking the data a much more nuanced question than just whether the dependent variable series showed a constant discrete shift at the moment of policy adoption, and sometimes the answer will be unclear. In that broader methodological light, it may not be so surprising that the evidence on the impact of unilateral divorce laws is ambiguous. 


\section{$\underline{\text { References }}$}

Angrist, Joshua D., and Jörn-Steffen Pischke. 2009. Mostly Harmless Econometrics: An Empiricist's Companion. Princeton: Princeton University Press.

Arellano, Manuel. 1987. “Computing Robust Standard Errors for Within-Groups Estimators.” Oxford Bulletin of Economics and Statistics, 49(4): 431-4.

Dickens, William T. 1990. “Error Components in Grouped Data: Is It Ever Worth Weighting?” Review of Economics and Statistics, 72(2): 328-33.

Dröes, Martijn I., and Ryan C.R. van Lamoen. 2010. “Did Unilateral Divorce Laws Raise Divorce Rates? A Reconciliation and New Results: Comment.” Discussion Paper No. 10-11, Tjalling C. Koopmans Research Institute, Utrecht School of Economics.

DuMouchel, William H., and Greg J. Duncan. 1983. “Using Sample Survey Weights in Multiple Regression Analyses of Stratified Samples.” Journal of the American Statistical Association, 78(383): 535-43.

Friedberg, Leora. 1998. “Did Unilateral Divorce Raise Divorce Rates? Evidence from Panel Data.” American Economic Review, 88(3): 608-27.

Nickell, Stephen. 1981. “Biases in Dynamic Models with Fixed Effects.” Econometrica, 49(6): 1417-26.

Solon, Gary. 1984. “Estimating Autocorrelations in Fixed-Effects Models.” Technical Working Paper No. 32, National Bureau of Economic Research.

Stevenson, Betsey, and Justin Wolfers. 2007. “Marriage and Divorce: Changes and Their Driving Forces.” Journal of Economic Perspectives, 21(2): 27-52.

Vogelsang, Timothy. 2008. "Heteroskedasticity, Autocorrelation, and Spatial Correlation Robust Inference in Linear Panel Models with Fixed Effects.” Unpublished.

Wolfers, Justin. 2006. “Did Unilateral Divorce Laws Raise Divorce Rates? A Reconciliation and New Results.” American Economic Review, 96(5): 1802-20. 
Table 1. Estimated Effects of Unilateral Divorce Laws with No Controls for State-Specific Time Trends

\begin{tabular}{|c|c|c|c|c|c|}
\hline & (1) & (2) & (3) & (4) & (5) \\
\hline $\begin{array}{l}\text { Dependent } \\
\text { variable: }\end{array}$ & Divorce rate & Divorce rate & Divorce rate & $\begin{array}{c}\text { Log of } \\
\text { divorce rate }\end{array}$ & $\begin{array}{c}\text { Log of } \\
\text { divorce rate }\end{array}$ \\
\hline $\begin{array}{l}\text { Estimation } \\
\text { method: }\end{array}$ & WLS & OLS & $\begin{array}{c}\text { WLS } \\
\text { excluding } \\
\text { California }\end{array}$ & WLS & OLS \\
\hline First 2 years & $\begin{array}{c}0.267 \\
(0.085) \\
{[0.188]}\end{array}$ & $\begin{array}{l}-0.219 \\
(0.192) \\
{[0.292]}\end{array}$ & $\begin{array}{c}0.071 \\
(0.093) \\
{[0.131]}\end{array}$ & $\begin{array}{l}-0.136 \\
(0.033) \\
{[0.114]}\end{array}$ & $\begin{array}{l}-0.091 \\
(0.028) \\
{[0.051]}\end{array}$ \\
\hline Years 3-4 & $\begin{array}{c}0.210 \\
(0.085) \\
{[0.159]}\end{array}$ & $\begin{array}{l}-0.273 \\
(0.194) \\
{[0.423]}\end{array}$ & $\begin{array}{c}0.123 \\
(0.093) \\
{[0.168]}\end{array}$ & $\begin{array}{l}-0.206 \\
(0.033) \\
{[0.132]}\end{array}$ & $\begin{array}{c}-0.114 \\
(0.029) \\
{[0.065]}\end{array}$ \\
\hline Years 5-6 & $\begin{array}{c}0.164 \\
(0.085) \\
{[0.171]}\end{array}$ & $\begin{array}{l}-0.425 \\
(0.198) \\
{[0.490]}\end{array}$ & $\begin{array}{c}0.097 \\
(0.092) \\
{[0.184]}\end{array}$ & $\begin{array}{c}-0.249 \\
(0.033) \\
{[0.144]}\end{array}$ & $\begin{array}{l}-0.152 \\
(0.029) \\
{[0.076]}\end{array}$ \\
\hline Years 7-8 & $\begin{array}{c}0.158 \\
(0.084) \\
{[0.174]}\end{array}$ & $\begin{array}{l}-0.452 \\
(0.200) \\
{[0.477]}\end{array}$ & $\begin{array}{c}0.103 \\
(0.091) \\
{[0.190]}\end{array}$ & $\begin{array}{l}-0.270 \\
(0.032) \\
{[0.151]}\end{array}$ & $\begin{array}{l}-0.171 \\
(0.029) \\
{[0.081]}\end{array}$ \\
\hline Years 9-10 & $\begin{array}{l}-0.121 \\
(0.084) \\
{[0.163]}\end{array}$ & $\begin{array}{l}-0.703 \\
(0.203) \\
{[0.479]}\end{array}$ & $\begin{array}{c}-0.144 \\
(0.090) \\
{[0.178]}\end{array}$ & $\begin{array}{l}-0.331 \\
(0.032) \\
{[0.157]}\end{array}$ & $\begin{array}{l}-0.220 \\
(0.030) \\
{[0.083]}\end{array}$ \\
\hline Years 11-12 & $\begin{array}{c}-0.324 \\
(0.083) \\
{[0.180]}\end{array}$ & $\begin{array}{l}-0.741 \\
(0.203) \\
{[0.503]}\end{array}$ & $\begin{array}{l}-0.262 \\
(0.090) \\
{[0.187]}\end{array}$ & $\begin{array}{l}-0.376 \\
(0.032) \\
{[0.165]}\end{array}$ & $\begin{array}{l}-0.234 \\
(0.030) \\
{[0.085]}\end{array}$ \\
\hline Years 13-14 & $\begin{array}{l}-0.461 \\
(0.084) \\
{[0.199]}\end{array}$ & $\begin{array}{l}-0.845 \\
(0.212) \\
{[0.544]}\end{array}$ & $\begin{array}{l}-0.390 \\
(0.091) \\
{[0.211]}\end{array}$ & $\begin{array}{l}-0.419 \\
(0.032) \\
{[0.170]}\end{array}$ & $\begin{array}{l}-0.265 \\
(0.031) \\
{[0.088]}\end{array}$ \\
\hline Years 15+ & $\begin{array}{l}-0.507 \\
(0.080) \\
{[0.233]}\end{array}$ & $\begin{array}{l}-0.776 \\
(0.208) \\
{[0.472]}\end{array}$ & $\begin{array}{l}-0.348 \\
(0.090) \\
{[0.224]}\end{array}$ & $\begin{array}{l}-0.493 \\
(0.031) \\
{[0.188]}\end{array}$ & $\begin{array}{l}-0.326 \\
(0.031) \\
{[0.098]}\end{array}$ \\
\hline
\end{tabular}

Notes: Divorce rate is number of divorces per 1,000 persons by state and year. Standard error estimates in parentheses assume homoskedasticity and serial non-correlation. Standard error estimates in brackets are robust to heteroskedasticity and serial correlation. All regressions include controls for year and state fixed effects. 
Table 2. Estimated Effects of Unilateral Divorce Laws with Controls for Linear State-Specific Time Trends

\begin{tabular}{|c|c|c|c|c|c|}
\hline & (1) & (2) & (3) & (4) & (5) \\
\hline $\begin{array}{l}\text { Dependent } \\
\text { variable: }\end{array}$ & Divorce rate & Divorce rate & Divorce rate & $\begin{array}{l}\text { Log of } \\
\text { divorce rate }\end{array}$ & $\begin{array}{c}\text { Log of } \\
\text { divorce rate }\end{array}$ \\
\hline $\begin{array}{l}\text { Estimation } \\
\text { method: }\end{array}$ & WLS & OLS & $\begin{array}{l}\text { WLS } \\
\text { excluding } \\
\text { California }\end{array}$ & WLS & OLS \\
\hline First 2 years & $\begin{array}{l}0.342 \\
(0.062) \\
{[0.196]}\end{array}$ & $\begin{array}{c}0.141 \\
(0.096) \\
{[0.112]}\end{array}$ & $\begin{array}{c}0.104 \\
(0.066) \\
{[0.095]}\end{array}$ & $\begin{array}{c}-0.022 \\
(0.020) \\
{[0.063]}\end{array}$ & $\begin{array}{l}-0.017 \\
(0.018) \\
{[0.026]}\end{array}$ \\
\hline Years 3-4 & $\begin{array}{l}0.319 \\
(0.070) \\
{[0.154]}\end{array}$ & $\begin{array}{c}0.211 \\
(0.107) \\
{[0.120]}\end{array}$ & $\begin{array}{c}0.170 \\
(0.073) \\
{[0.133]}\end{array}$ & $\begin{array}{c}-0.049 \\
(0.023) \\
{[0.063]}\end{array}$ & $\begin{array}{l}-0.014 \\
(0.020) \\
{[0.031]}\end{array}$ \\
\hline Years 5-6 & $\begin{array}{l}0.300 \\
(0.077) \\
{[0.174]}\end{array}$ & $\begin{array}{c}0.177 \\
(0.121) \\
{[0.180]}\end{array}$ & $\begin{array}{c}0.152 \\
(0.080) \\
{[0.153]}\end{array}$ & $\begin{array}{l}-0.051 \\
(0.025) \\
{[0.064]}\end{array}$ & $\begin{array}{l}-0.022 \\
(0.023) \\
{[0.034]}\end{array}$ \\
\hline Years 7-8 & $\begin{array}{c}0.322 \\
(0.084) \\
{[0.195]} \\
\end{array}$ & $\begin{array}{c}0.250 \\
(0.132) \\
{[0.283]}\end{array}$ & $\begin{array}{c}0.172 \\
(0.087) \\
{[0.177]} \\
\end{array}$ & $\begin{array}{l}-0.033 \\
(0.028) \\
{[0.065]}\end{array}$ & $\begin{array}{l}-0.013 \\
(0.025) \\
{[0.039]}\end{array}$ \\
\hline Years 9-10 & $\begin{array}{c}0.081 \\
(0.091) \\
{[0.206]}\end{array}$ & $\begin{array}{c}0.133 \\
(0.143) \\
{[0.370]}\end{array}$ & $\begin{array}{l}-0.049 \\
(0.094) \\
{[0.202]}\end{array}$ & $\begin{array}{l}-0.052 \\
(0.030) \\
{[0.067]}\end{array}$ & $\begin{array}{l}-0.030 \\
(0.027) \\
{[0.046]}\end{array}$ \\
\hline Years 11-12 & $\begin{array}{l}-0.102 \\
(0.099) \\
{[0.223]}\end{array}$ & $\begin{array}{c}0.144 \\
(0.154) \\
{[0.424]}\end{array}$ & $\begin{array}{l}-0.164 \\
(0.101) \\
{[0.240]}\end{array}$ & $\begin{array}{l}-0.051 \\
(0.032) \\
{[0.074]}\end{array}$ & $\begin{array}{l}-0.015 \\
(0.029) \\
{[0.052]}\end{array}$ \\
\hline Years 13-14 & $\begin{array}{l}-0.202 \\
(0.107) \\
{[0.236]}\end{array}$ & $\begin{array}{c}0.210 \\
(0.168) \\
{[0.484]}\end{array}$ & $\begin{array}{l}-0.270 \\
(0.109) \\
{[0.248]}\end{array}$ & $\begin{array}{l}-0.043 \\
(0.035) \\
{[0.077]}\end{array}$ & $\begin{array}{l}-0.005 \\
(0.032) \\
{[0.060]}\end{array}$ \\
\hline Years 15+ & $\begin{array}{l}-0.210 \\
(0.119) \\
{[0.263]}\end{array}$ & $\begin{array}{c}0.311 \\
(0.187) \\
{[0.540]}\end{array}$ & $\begin{array}{l}-0.246 \\
(0.121) \\
{[0.275]}\end{array}$ & $\begin{array}{c}0.006 \\
(0.039) \\
{[0.084]}\end{array}$ & $\begin{array}{c}0.026 \\
(0.035) \\
{[0.073]}\end{array}$ \\
\hline
\end{tabular}

Notes: Divorce rate is number of divorces per 1,000 persons by state and year. Standard error estimates in parentheses assume homoskedasticity and serial non-correlation. Standard error estimates in brackets are robust to heteroskedasticity and serial correlation. All regressions include controls for year and state fixed effects. 
Table 3. Estimated Effects of Unilateral Divorce Laws with Controls for Quadratic State-Specific Time Trends

\begin{tabular}{|c|c|c|c|c|c|}
\hline & (1) & (2) & (3) & (4) & (5) \\
\hline $\begin{array}{l}\text { Dependent } \\
\text { variable: }\end{array}$ & Divorce rate & Divorce rate & Divorce rate & $\begin{array}{c}\text { Log of } \\
\text { divorce rate }\end{array}$ & $\begin{array}{c}\text { Log of } \\
\text { divorce rate }\end{array}$ \\
\hline $\begin{array}{l}\text { Estimation } \\
\text { method: }\end{array}$ & WLS & OLS & $\begin{array}{c}\text { WLS } \\
\text { excluding } \\
\text { California }\end{array}$ & WLS & OLS \\
\hline First 2 years & $\begin{array}{c}0.302 \\
(0.054) \\
{[0.169]}\end{array}$ & $\begin{array}{c}0.050 \\
(0.075) \\
{[0.089]}\end{array}$ & $\begin{array}{c}0.110 \\
(0.059) \\
{[0.093]}\end{array}$ & $\begin{array}{l}-0.021 \\
(0.020) \\
{[0.053]}\end{array}$ & $\begin{array}{l}-0.015 \\
(0.018) \\
{[0.021]}\end{array}$ \\
\hline Years 3-4 & $\begin{array}{c}0.289 \\
(0.065) \\
{[0.127]}\end{array}$ & $\begin{array}{c}0.062 \\
(0.092) \\
{[0.143]}\end{array}$ & $\begin{array}{c}0.198 \\
(0.072) \\
{[0.131]}\end{array}$ & $\begin{array}{l}-0.047 \\
(0.025) \\
{[0.054]}\end{array}$ & $\begin{array}{c}-0.014 \\
(0.022) \\
{[0.026]}\end{array}$ \\
\hline Years 5-6 & $\begin{array}{l}0.291 \\
(0.079) \\
{[0.141]}\end{array}$ & $\begin{array}{l}-0.036 \\
(0.116) \\
{[0.179]}\end{array}$ & $\begin{array}{c}0.203 \\
(0.090) \\
{[0.160]}\end{array}$ & $\begin{array}{l}-0.046 \\
(0.030) \\
{[0.056]}\end{array}$ & $\begin{array}{c}-0.022 \\
(0.028) \\
{[0.033]}\end{array}$ \\
\hline Years 7-8 & $\begin{array}{l}0.351 \\
(0.097) \\
{[0.165]}\end{array}$ & $\begin{array}{l}-0.026 \\
(0.144) \\
{[0.205]}\end{array}$ & $\begin{array}{c}0.257 \\
(0.111) \\
{[0.202]}\end{array}$ & $\begin{array}{l}-0.019 \\
(0.037) \\
{[0.061]}\end{array}$ & $\begin{array}{c}-0.008 \\
(0.035) \\
{[0.043]}\end{array}$ \\
\hline Years 9-10 & $\begin{array}{c}0.161 \\
(0.117) \\
{[0.172]}\end{array}$ & $\begin{array}{l}-0.210 \\
(0.177) \\
{[0.240]}\end{array}$ & $\begin{array}{c}0.076 \\
(0.137) \\
{[0.232]}\end{array}$ & $\begin{array}{l}-0.028 \\
(0.045) \\
{[0.069]}\end{array}$ & $\begin{array}{l}-0.018 \\
(0.043) \\
{[0.056]}\end{array}$ \\
\hline Years 11-12 & $\begin{array}{c}0.047 \\
(0.142) \\
{[0.190]}\end{array}$ & $\begin{array}{l}-0.270 \\
(0.215) \\
{[0.278]}\end{array}$ & $\begin{array}{c}0.006 \\
(0.167) \\
{[0.280]}\end{array}$ & $\begin{array}{c}-0.014 \\
(0.054) \\
{[0.088]}\end{array}$ & $\begin{array}{c}0.005 \\
(0.052) \\
{[0.070]}\end{array}$ \\
\hline Years 13-14 & $\begin{array}{c}0.031 \\
(0.167) \\
{[0.211]}\end{array}$ & $\begin{array}{l}-0.289 \\
(0.257) \\
{[0.328]}\end{array}$ & $\begin{array}{l}-0.047 \\
(0.199) \\
{[0.310]}\end{array}$ & $\begin{array}{c}0.011 \\
(0.063) \\
{[0.098]}\end{array}$ & $\begin{array}{c}0.029 \\
(0.063) \\
{[0.086]}\end{array}$ \\
\hline Years 15+ & $\begin{array}{c}0.251 \\
(0.205) \\
{[0.261]}\end{array}$ & $\begin{array}{l}-0.226 \\
(0.317) \\
{[0.407]}\end{array}$ & $\begin{array}{c}0.074 \\
(0.242) \\
{[0.341]}\end{array}$ & $\begin{array}{c}0.104 \\
(0.078) \\
{[0.113]}\end{array}$ & $\begin{array}{c}0.087 \\
(0.077) \\
{[0.107]}\end{array}$ \\
\hline
\end{tabular}

Notes: Divorce rate is number of divorces per 1,000 persons by state and year. Standard error estimates in parentheses assume homoskedasticity and serial non-correlation. Standard error estimates in brackets are robust to heteroskedasticity and serial correlation. All regressions include controls for year and state fixed effects. 